\author{
Journal of Music Science, Technology, \\ and Industry \\ Volume 3, Number 2, 2020 \\ e-ISSN. 2622-8211 \\ https://jurnal.isi-dps.ac.id/index.php/jomsti/
}

\title{
Max/Msp sebagai Medium Perluasan Perspektif Komponis pada Karya Musik Masa Kini
}

\author{
Candra Bangun Setyawan \\ Penciptaan Musik Barat, Pascasarjana ISI Yogyakarta, Indonesia \\ E-mail : candrabanguns@gmail.com
}

\begin{tabular}{l}
\hline Article Info \\
\hline \\
Article History: \\
Received: \\
June 2020 \\
Accepted: \\
September 2020 \\
Published: \\
October 2020
\end{tabular}

Keywords:

Technology,

computer,

software,

Max/msp,

creativity

\section{ABSTRACT}

Purpose: This study is to understand the integration of music and technology that has broadened various perspectives in representing experiences into musical works. Research methods: This article is a literature review about Max/Msp. It is a software based visual programming language for music and multimedia. Results and discussion: The emergence of Max offers a variety of possibilities related to the space of creativity, as well as having an impact on the loss of the boundaries of the creativity process. On the other hand, from the many possibilities that can be offered, access and availability of books related to Max are still very limited in Indonesia. Implication: Max contributes in expanding musical works through various new perspectives.

(C) 2020 Institut Seni Indonesia Denpasar

PENDAHULUAN

Teknologi informasi dan komunikasi di awal abad ke-21 telah membawa ke dalam tatanan kehidupan yang kompleks sarat akan perubahan dan keterbukaan. Pada saat ini masyarakat menuju pada informasi berteknologi maju yang dicirikan oleh berbagai aspek perkembangan, baik ilmu pengetahuan, teknologi, sains, sosial, pilitik, keterkaitan global, infrastruktur, dan menuntut sumber daya manusia yang kreatif dan inovatif. Dari perkembangan yang pesat telah melahirkan berbagai jenis pengalaman baru yang berbeda, sehingga suatu 
persoalan terkait hubungan "linier" sudah tidak terlalu dipersoalkan, melainkan bagaimana melihat kembali sesuatu yang lebih luas berkaitan dengan berbagai aspek disiplin. Bagi komponis munculnya fenomena tersebut merupakan sebuah tanda terkait munculnya ruang kreatifitas, tanda ini kemungkinan memberikan bentuk keterbukaan dalam menjelajahi berbagai bentuk pendekatan-pendekatan baru.

Proses kreatif dalam penciptaan karya musik tidak lepas dari pengalaman komponis, pengalaman sering kali dijadikan pemantik awal munculnya ide dan gagasan pada proses komposisi musik. Rahardjo (1993: 17) mengatakan bahwa "pengalaman adalah kejadian yang pernah dialami (pernah menjalani dan merasakan) baik yang sudah lama atau bisa yang baru saja terjadi". Pada saat ini pengalaman sering kali dibenturkan dengan berbagai fenomena baru yang muncul akibat perkembangan global, sehingga ide dalam penciptaan komposisi musik menjadi tidak terbatas. Banyak komponis yang mulai memasuki ranah lintas disiplin keilmuannya, tidak kecuali dalam perkembangan teknologi.

Teknologi menjadi salah satu media dalam menghubungkan bebagai jenis disiplin ilmu saat ini, munculnya teknologi komputer banyak memberi pengaruh terhadap berbagai bidang salah satunya pada bidang musik. Bagi komponis masa kini komputer telah menjadi sebuah bagian dari ruang kreatif (berkaitan dengan studio hingga instrument), dalam membuka berbagai kemungkinan baru terkait pengalaman, ide, gagasan hingga ekspresi. Komputer menyugukan sebuah realitas yang bisa digunakan dalam menerobos batasan-batasan ide maupum gagasan. Dengan bantuan komputer seorang komponis memiliki kemungkinan dalam memperluas musik melalui pendekatan yang dapat dihasilkan dari pembauran teknologi dan disiplin ilmu lain, seperti pendekatan interdisiplin, transdisipliner hingga pendekatan terkini.

Munculnya kemungkinan baru dalam memasuki wilayah tersebut, pada dasarnya tidak lepas dari perkembangan perangkat lunak "software". Dari perkembangan software inilah, berbagai macam ide kreatif dapat dituangkan. Banyaknya software musik seperti DAW "Digital Audio Workstation" hingga 
software berbasis programming, telah banyak memberi pilihan dalam membantu menentukan proses kreatif. Namun, dari banyaknya software musik yang ada, software berbasis programming lebih banyak menyuguhkan berbagai kemungkinan kreatif maupun ekspresi. Karena software berbasis programming memilik fleksibelitas dan interaktif yang lebih luas, sehingga proses pengolahan suara dapat berkembang seiring perkembangan zaman, mulai dari bentuk perpaduan visual, kinetic hingga pembutaan instrument baru yang berbasis teknologi.

Melihat urain di atas fungsi software menjadi sangat beragram dalam wilayah proses kreatif, menyangkut tentang kebebasan dalam menuangkan ide maupun gagasan secara luas. Banyaknya komponis yang mulai menerobos batasan proses kreativitas, telah memancing berbagai macam pendekatan "interdisipliner hingga transdisipliner". Artinya komponis tidak hanya berfokus pada bunyi melaikan penggunaan aspek diluar musik, hal ini dapat dilihat dari munculnya musik multimedia (Hidayatullah, (2020); https://jurnal.isidps.ac.id/index.php/jomsti/article/view/965), interaktif hingga musik generatif. Proses mencapai tahap tersebut tidak bisa secara mentah-mentah hanya menuangkan ide, maupun gagasan, komponis harus berpikir bagaimana cara merealisasikannya. Untuk memperluas karya musik melalui pendekatan terkini, teknologi telah menyuguhkan berbagai macam kemungkinan dalam membantu kebutuhan kreatifitas komponis. Tulisan ini bertujuan untuk melihat sejauh mana software Max/msp dapat digunakan dalam memperluas karya musik melalui perspektif baru.

\section{METODE}

Penulisan artikel ini menggunakan pendekatan studi pustaka dengan meninjau berbagai literatur terkait kemungkinan-kemungkinan yang bisa dimunculkan pada software Max/msp. Studi kepustakaan adalah suatu studi yang memperoleh atau mengumpulkan data dari berbagai sumber yang telah ada (peneliti sebagai tenaga kedua). Data dapat diperoleh dari berbagai sumber, penelitian terapan tidak lepas dari teori-teori utama pada landasan berfikir 
(kerangka teori). Untuk keperluan ini, diperlukan berbagai literatur untuk melakukan studi pustaka, pada penelitian bersifat kualitatif penggunaan literatur menjadi cukup dominan. Untuk menganalisis data teknik yang digunakan dapat diperoleh berdasarkan kemungkinan penarikan kesimpulan dan pengambilan tindakan yang bersifat naratif, yaitu dengan menarik kesimpulan atau verifikasi untuk membentuk data yang relevan dengan tujuan penulisan.

\section{HASIL DAN PEMBAHASAN}

Seni telah mengalami pembauran dengan berbagai cabang ilmu sejak beberapa puluh tahun yang lalu, saat ini banyak cabang ilmu yang telah terhubung dengan seni salah satunya teknologi. Seni memberi semacam persepsi mengenai pemaknaan atas sebuah pengalaman yang dituangkan melalui karya. Munculnya pendekatan baru telah banyak memunculkan berbagai macam krativitas dan inovasi. Pendekatan ini pada dasarnya memiliki tujuan untuk melakukan pemecahan masalah secara bersama, seperti menggunakan dua ilmu atau lebih (interdisipliner, transdisipliner hingga pendekatan-pendekatan baru).

Perkembangan teknologi pada dasarnya memiliki tujuan untuk memudahkan manusia dalam menjalani kehidupan. Pemahaman umum tentang teknologi sebagai perpanjangan dari sains modern yang dianggap selalu berurusan dengan kepastian rasional dan serba terukur. Dalam logika positivisme sering terungkap dalam dialektik yang mempertentangkan praksis sains dan teknologi secara bipolar. Sedangkan pada disiplin seni khususnya pada seni masa kini "contemporary", umumnya sering dilihat sebagai praksis filosofis yang justru identik dengan berbagai ketidakpastian, tehadap penafsiran personal dan subjektifitas (Hujatkajennong, 2015).

Istilah seni digital digunakan untuk menandai praktik seni yang menggunakan teknologi komputer sebagai media kreatif. Istilah tersebut seringkali digunakan secara berbeda, seperti "seni teknologi" (Steve Dietz), "seni electronic" (Lev Manovic), "seni internet" (Jon Ippolito), dan "seni media baru" pada seni visual. Istilah media baru dianggap payung dari semua jenis praktik 
seni yang menggunakan peralatan electronic, teknologi komputer, dan alat komunikasi baru. Seni generatif mengacu pada seni yang secara keseluruhan atau sebagian telah dibuat dengan menggunakan sistem otonom. Sistem otonom dalam konteks ini pada umumnya adalah yang non-manusia dan secara mandiri dapat menentukan parameter dari suatu karya seni dengan memerlukan keputusan yang diambil langsung oleh seniman. Meskipun demikian, istilah seni digital dan media baru masih sering digunakan secara bergantian. Pada seni musik teknologi komputer sangat memberikan keluasan bagi musicology, musician, education hingga composition.

Perkembangan komputer semakin komplek dengan penggunaan kapasitas yang cukup besar, pada saat ini komputer sudah mengalami sesuatu perubahan yang komplek, hal ini juga didukung dengan munculnya berbagai perangkat lunak "software". Selain itu, munculnya beberapa bahasa pemrograman yang digunakan dalam membatuh bidang musik (analisis, ekspresi hingga proses kreatif) seperti Python, Javascript, $\mathrm{C}++$. processing hingga penggunaan berbagai macam algoritma, seperti algoritma Markov Chain yang digunakan untuk melakukan automatic music composition. dimana menggunakan probabilitas yang telah muncul di masa lalu dan sekarang. Musik komputer merupakan bagian dari aplikasi teknologi komputasi dengan mencakup teori, pengaplikasian perangkat lunak komputer yang baru dan memiliki aspekaspek dasar musik, seperti sound design "sintesis suara", pemrosesan sinyal digital", difusi sonic, akustik, dan psikoakustik.

Bidang musik komputer dapat melacak kembali ke asal-usul musik electronic, dan percobaan dan inovasi pertama dengan instrument electronic pada pergantian abad ke-20. Seperti yang dikatakan oleh François Bayle, "Komputer itu bukan alat tetapi agak mirip dengan bengkel, artinya semua orang bisa membentuknya untuk mendefinisikan dunianya sendiri, untuk merancang nada dan waktunya sendiri". Munculnya berbagai pendekatan, seperti intersisipliner hingga transdisipliner dapat dianggap sebagai kaeadaan sementara, karena bidang penelitian, seperti komposisi musik, studi budaya, sosial, musikologi, psikologi, hingga komputasi cenderung berubah secara 
bertahap menjadi disiplin atau paradigma baru, sehingga munculnya Max/Msp telah menawarkan sebuah ruang baru dalam menyikapi munculnya berbagai paradikma baru khususnya dalam bidang musik.

\section{Max/Msp}

Max/Msp adalah bahasa pemrograman visual untuk musik dan multimedia yang dikembangkan dan dikelola oleh perusahaan perangkat lunak yang berbasis di San Francisco "Cycling '74". Lebih dari tiga puluh tahun sejarahnya, telah digunakan oleh komponis, musisi, perancang perangkat lunak, peneliti, dan seniman untuk membuat rekaman, pertunjukan, dan instalasi. Program Max bersifat modular, dengan sebagian besar penggunaannya ada pada sebagai perpustakaan bersama. Application Programming Interface (API) yang memungkinkan untuk pengembangan baru pada pihak ketiga (bernama objek eksternal).

Max telah digambarkan sebagai bahasa perancis untuk mengembangkan perangkat lunak untuk kinerja musik interaktif hingga Live Coding. Live coding dalam musik adalah praktek improvisasi berdasarkan kode menghasilkan secara real time dengan baik menulis secara langsung atau menggunakan pemrograman interaktif (Brown. 2006). Fungsi Max dalam membawa komponis pada berbagai macam pendekatan masih sangat luas, hal ini dikarenakan Max menawarkan berbagai macam objek yang akan terus berkembang seiring perkembangan zaman, seperti sound design, visual "jitter" hingga memperluas dengan berbagai software dan hardware lain.

\section{Sound Syntesiss}

Penggunaan komputer dalam musik telah memberi kemungkinan bagi seniman untuk mengelola dan memanipulasi bunyi dengan akurat dan bebas, yang tidak terpikirkan atau tidak mungkin dilakukan dengan instrument akustik. Dilain sisi, komposer tradisional yang bekerja dengan instrument tradisional menyusun dengan menggunakan bunyi yang telah ada, namun pada komposer electronic menyusun bunyi dengan sendiri. Hal ini sama juga terjadi pada grafik animasi, berkat komputer untuk membuat gambar dan urutan film yang sangat realistis, 
dan tidak mungkin bisa dihasilkan dengan cara lain. Hampir semua efek khusus sinematik sekarang diproduksi dengan komputer sudah menjadi hal biasa untuk menemukan entitas virtual.

Seorang komponis memiliki imajinasi terkait sumber bunyi yang diinginkan untuk mewujutkan karya seni musik yang sesuai dengan ide. Melalui teknologi komputasi Peter Meanning (1993) dalam buku Electronic and Computer Music memaparkan bahwa teknologi komputasi yang saat ini memiliki kecerdasan buatan yang baik, maka tidak sulit untuk mewujudkan bunyi yang ingin diwujudkan. Kemungkinan-kemungkinan baru yang ditemukan ini pada dasarnya adalah hasil perpindahan dari dunia analog ke dunia digital. Setelah gambar atau suara diubah menjadi urutan angka, angka-angka itu dapat mengalami transformasi, karena angka-angka tersebut dengan mudah dan efisien dianalisis dan dimanipulasi oleh komputer.

Sedangkan pada praktiknya kemungkinan untuk membuat bunyi sebagian besar didasarkan pada beberapa parameter yang dipilih, dan dapat memperoleh sonority yang ingin dicari dengan cara memanipulasi parameter. Max menawarkan beberapa kemungkinan dalam sintesis suara, antara lain Delay lines, reverberation, spatialization, digital audio and sampled sounds, MIDI, OSC dan realtime synthesis, serta berkaitan dengan teknik non-linear (seperti sintesis AM dan FM), sintesis granular, analisis dan resintesis, konvolusi, pemodelan fisik, hingga mikromontage.

\section{Signal Processing}

Pemrosesan sinyal merupakan tindakan memodifikasi suara yang dihasilkan secara langsung, misalnya melalui mikrofon, atau dari file audio yang sudah ada yang sebelumnya yang telah tersimpan pada file komputer. Kemungkinan dalam melakukan pemrosesan sinyal bisa melalui berbagai cara, dengan melihat kemungkinan suara yang sudah ada sebelumnya. Artinya penyimpanan secara terpisah pada file suara yang akan diproses secara offline, misalnya direkam ke disk menggunakan mikrofon yang terhubung dengan audio interface, dengan tujuan melakukan konversi analog ke digital. Penerapkan algoritma pada 
dasarnya untuk menentukan modifikasi atau manipulasi yang akan dibuat untuk file audio asli. Setelah dieksekusi, program ini akan membuat file audio baru yang berisi suara yang dimodifikasi atau manipulasi. Berikut gambar proses sound processing.
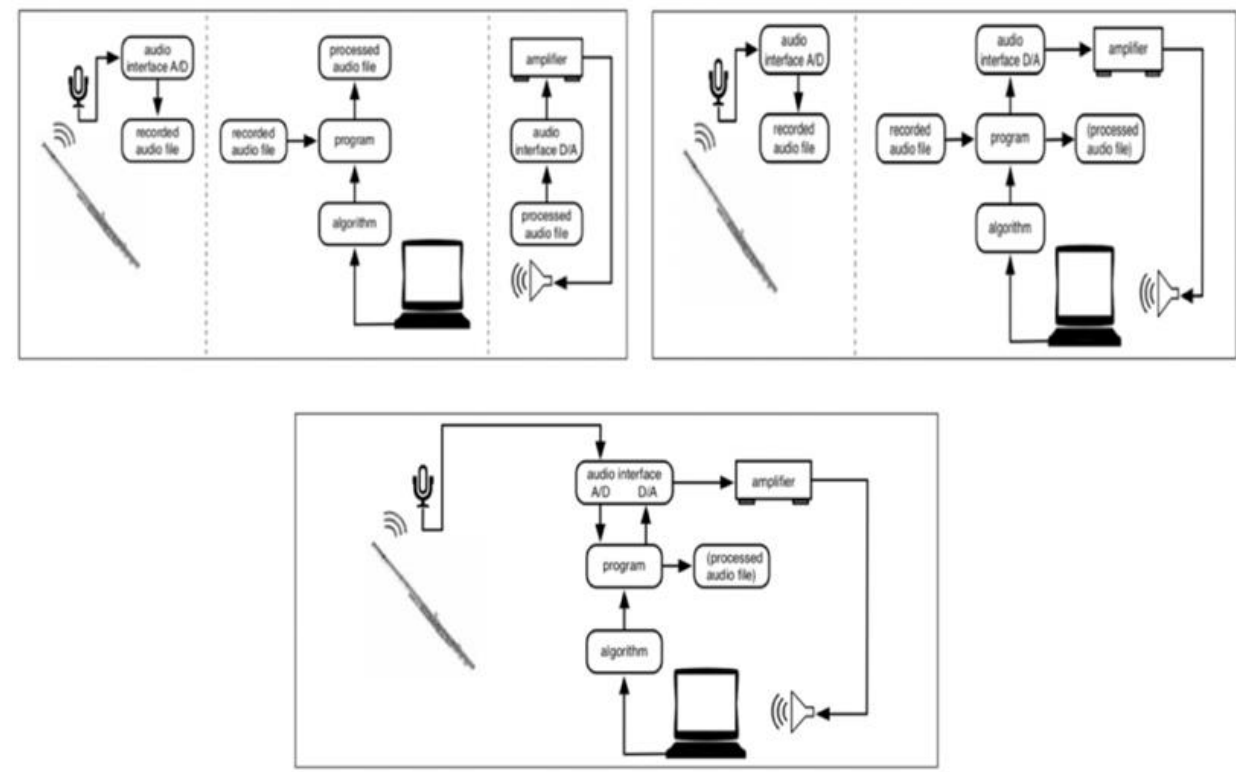

Gambar 1: Skema offline sound processing realtime, sound processing on pre-existing sound dan realtime sound processing on live sound

Sumber : buku. electronic music and sound design theory and practice with max and msp - volume 1

Melihat uraian di atas dapat dimungkinkan Max memiliki kemungkinan dalam menghasilkan suara buatan maupun baru, dengan menggunakan bahasa pemrograman yang dirancang sendiri untuk menghasilkan sintesis bunyi dan pemrosesan sinyal berdasarkan kebutuhan. Komponis dapat menentukan bunyi yang diinginkan dengan membangun "mesin virtual" pada Max dengan desain yang di inginan atau yang diwujudkan sebagai algoritma, sehingga dengan menentukan serangkaian instruksi yang mana mesin ini akan digunakan untuk membuat kebutuah suara yang di inginkan. 


\section{Jitter}

Keleluasan Max pada dasarnya dapat memberikan keluasan dalam menampung ide kreatif komponis, tidak hanya berbasis audio, Max dapat digunakan untuk beberapa objek yang berkaitan dengan visual. Jitter merupakan nama objek pada Max yang berfungsi sebagai visual, jitter meliputi banyak objek, seperti 3D, text, webcam, vr, movie dll. Dengan jitter komponis dapat menggunakan visual mati maupun visual hidup pada karya musik, visual hidup pada Max memiliki peluang interaktif dengan audio hingga gerak. Jitter memberikan keluasaan bagi komponis dalam menjelajahi seni visual dan mengkoneksikan keduanya. Pada gambar dibawah ini merupakan contoh pengaturan jitter dengan menggunakan gerak tubuh melalui webcam.
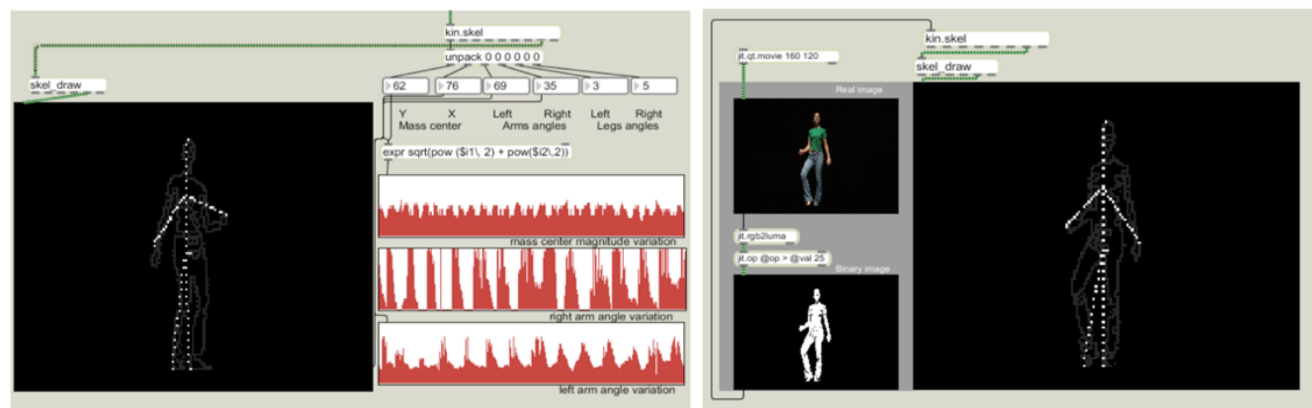

Gambar 2 : pengaturan jitter denganmenggunakan gerak tubuh melalui webcam Dokumen : Jurnal. A Real-Time Human Body Skeletonization Algorithm For Max/Msp/Jitter

Gambar di atas merupaka contoh pengembangan jitter melalui real-time Skeletonization dengan menggunakan tubuh manusia sebagai controler objek jitter. Sebuah algoritma untuk real-time skeletonization dengan menggunakan tubuh secara penuh dan visualisasi diimplementasikan sebagai dua objek eksternal untuk Jitter. Hal seperti ini dimaksudkan untuk memberikan gambaran yang akurat dari gerak tubuh seperti yang ditangkap oleh kamera video "webcam", yang akan digunakan sebagai pengendali irama musik dalam sistem musik secara interaktif. 


\section{Memperluas Max}

Max memiliki kemungkinan terkait keterbukaan dengan beberapa perangkat lunak "software" lain, seperti DAW "Ableton, Logic Pro dll", Touchdesigner, Resolume, Unity hingga bahasa Javascript. Hal ini yang membuat Max memiliki keleluasaan dalam menjelajah ruang baru. Selain itu, Max juga terbuka untuk perangkat keras "Hardware" seperti pada Android hingga Arduino yang berperan sebagai controller pada objek "Lampu, hingga sensor". Banyak sekali karya dengan memperluas Max menggunakan kombinasi software maupun hardware, seperti contoh pada karya "Instrument dan penciptaan visual yang didorong dengan sinyal biologis".

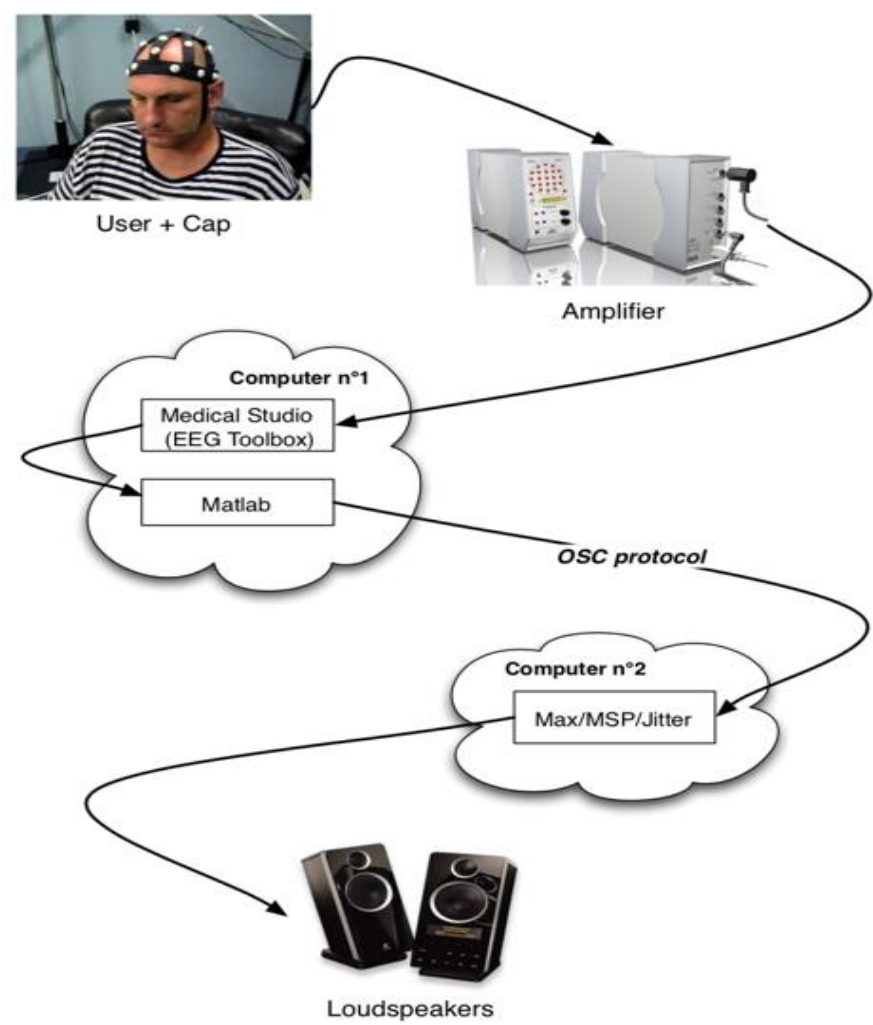

Gambar 3 : Skema karya Instrument dan penciptaan visual yang didorong dengan sinyal biologis

Dukumen : Jurnal. An instrument of sound and visual creation driven by biological signals 
Skema di atas merupakan salah satu contoh ketebukaan Max dengan berbagai software dan hardware, seperti penggunaan User + cup sebagai control, hingga software Medical Studio Lab. Instrument ini berjalan dengan menggunakan dua komputer, satu mengelola Medis Studio untuk menangkap EMG sinyal dan yang lain berjalan pada Max untuk menjalankan efek audio digital. EMG sinyal, ditangkap dengan studio medis, dipindahkan ke Max, di mana spektrum massa, entropi dan perhitungan kekuatan sinyal di sekitar pita frekuensi $8 \mathrm{~Hz}$. Sinyal ini dihasilkan berbeda-beda dipengaruhi oleh gerakan kaki dengan cara subjek mampu mengendalikan masing-masing, lebih atau kurang. Dua audio digital efek modul yang telah dirancang, entropi dari sinyal EMG, yang merupakan parameter yang paling mudah dikontrol, digunakan untuk memodifikasi frekuensi cutoff dari bandpass filter diterapkan pada suara. Efek modul audio kedua, menggunakan entropi sinyal EMG untuk mendorong dua pitch pergeseran proses simultan, satu bergerak ke bawah dan satu lagi bergerak ke atas. Pada dasarnya penjelasan karya di atas merupakan sebuah kontribusi instrument yang difokuskan pada pengembangan alat musik baru dengan mengaktifkan sinyal-sinyal listrik dari otak (EEG) dan otot (EMG).

Keluasan Max tidak hanya pada hubungan dengen control manusia melain juga berbagai media lain salah satunya pada game. Menggunakan Max yang dihubungkan dengan software unity baik melalui OSC "Open Sound Control', dimana komponis bisa bermain game dengan menggunakan alat musik. Unity3D adalah platform prototyping video game cepat 3D yang kuat dengan mesin fisika terintegrasi. Namun, kemampuan audionya terbatas terutama untuk memicu dan merasionalisasi buffer audio. Uniknya toolkit menawarkan integrasi Max dengan Unity3D yang mudah, memungkinkan untuk pertukaran data kontrol, serta mengimpor tekstur Jitter dinamis ke Unity3D. Yang pertama membuatnya sangat cocok untuk sonifikasi simulasi fisika yang efisien. Unity telah digunakan di instalasi suara interaktif komunal memungkinkan gerak pengunjung (Max) untuk mengendarai mesin fisika (Unity3D) dan sonify data berikutnya di 12channel ceiling-mount array speaker (Max). 

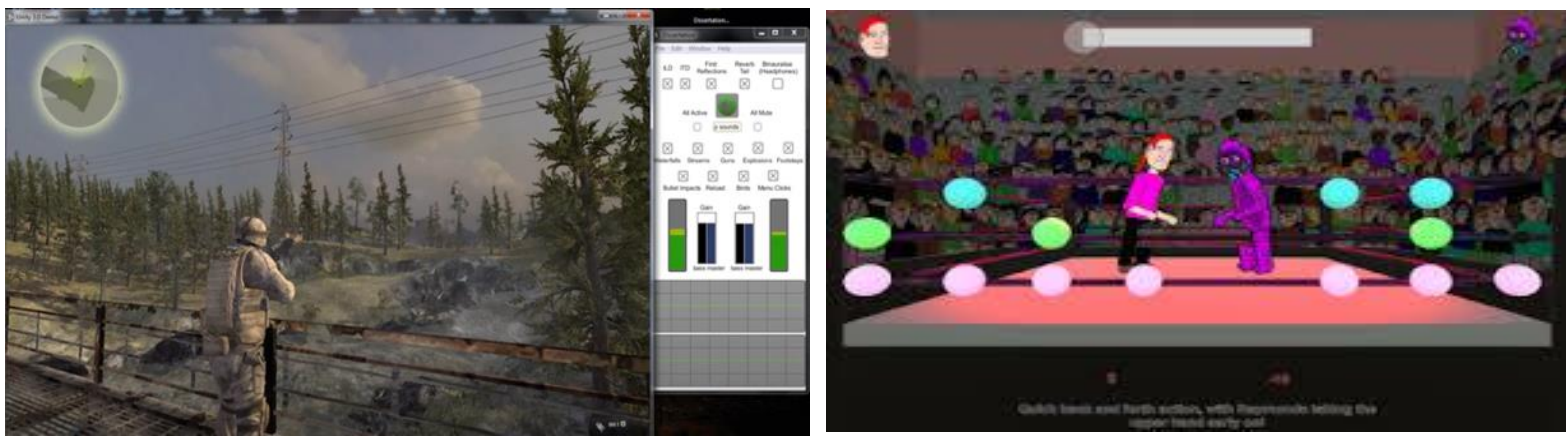

Gambar 4: Penggunaan Max yang terhubung pada unity

Peningkatan daya pemrosesan dan keterjangkauan perangkat komputasi telah mengantarkan revolusi alat prototyping ke arah perangkat lunak cepat. Melalui penggunaan perpustakaan pintas yang dirancang untuk serangkaian tugas tertentu, lingkungan pengembangan seperti itu menawarkan efisiensi yang belum pernah terjadi sebelumnya. Dalam domain audio, bahkan alat yang paling awal, seperti gramatika musik. Elemental telah banyak berfungsi sebagai uji kemampuan untuk menyediakan cara yang stabil dan terukur untuk mengintegrasikan Max dan Unity3D ke dalam alat prototyping.

Tidak hanya pada koneksi dengan berbagai software, Max juga dapat dikombinasi dengan perangkat keras Arduino. Arduino adalah sebuah platform komputasi fisik open source berbasiskan Rangkain input / output sederhana (I/O) dan lingkungan pengembangan yang mengimplementasikan bahasa Processing. Arduino dapat digunakan untuk mengembangkan obyek interaktif mandiri atau dapat dihubungkan ke perangkat lunak pada komputer anda (seperti Flash, Pengolahan, VVVV, atau Max / MSP). Rangkaiannya dapat dirakit dengan tangan atau dibeli. IDE (Integrated Development Environment) Arduino bersifat open source.

\section{KESIMPULAN}

Kreativitas dalam komposisi musik saat ini menjadi sangat luas. Hal ini memungkinkan bagi komponis pada masa kini untuk membuat sebuah komposisi musik yang bersumber dari berbagai macam ide dan berbagai macam 
pendekatan. Perkembangan teknologi dan ilmu pengetahuan yang sangat pesat telah menwarkan berbagai macam ruang baru, pembauran antaran seni musik dengan disiplin ilmu lain (sains, hingga teknologi). Memunculkan berbagai macam perspektif baru dalam berkarya musik, Max hanyalah sebagian dari perkembangan teknologi yang menawarkan berbagai macam perspektif baru dalam menjelajahi musik masa kini. Munculnya paradikma baru yang terus berkembang memberikan sikap bagi komponis dalam memperluas karya musik, Max mungkin sudah dirancang oleh pembuatnya untuk dapat mengikuti perkembangan zaman.

\section{REFERENSI}

Baltazar. andre. a real-time human body skeletonization algorithm for max/msp/jitter. inesc porto and portuguese catholic university - school of the arts

B. Arslan, A. Brouse, C. Simon, R. Lehembre, J. castet, J.J. Filatriau, Q. Noirhomme. 2006. a real time music synthesis environment driven with biological signals, icassp.

Bukvic. ivica ico. max-unity3d interoperability toolkit. virginia tech music, disis, cctad.

Caplan, David. 2006. Questions of possibility: contemporary poetry and poetic form. Oxford University Press, US.

Cipriani, Alessandro. Giri, Maurizio. electronic music and sound design theory and practice with max and msp - volume 1. contemponet s.a.s. rome italy.

Cycling'74. max/msp a graphical programming environment for music, audio, and multimedia. Dikutip dari: http://www.cycling74.com/pro.

DeSantis. Dennis. 2015. Making Music 74 Creative Strategies for Electronic Music Producers. Ableton AG Schönhauser Allee 6-7. Germany.

Hidayatullah, R. (2020). MERLOT: Belajar Musik di Era Digital. Journal of Music Science, Technology, and Industry, 3(1), 75-90. Dikutip dari: https://jurnal.isi-dps.ac.id/index.php/jomsti/article/view/965.

Kostka, Stefan. 2006. Materials and Techniques of Twentieth-Century Music, Third Edition. New Jersey.

Meanning. Peter. 1993. dalam buku Electronic and Computer Music. Oxford University Press, US.

Miranda. Eduardo Reck. 2002. Computer Sound Design Synthesis techniques and programming. Linacre House, Jordan Hill, Oxford OX2 8DP

Roberts, S. 2011. Metacognition in music performance: A practical approach to implementing self-assessment and evaluation learning activities into teaching practice. Making Sound Waves: Diversity, Unity, Equity: Proceedings of the XVIII National Conference, 170-177. 
Rubisch Julian. 2009. Generative Music for Media Applications (GeMMA) -

Towards Automated Design and Production of Media Related Music. University of Applied Sciences St. Austria.

Russ. Martin. 2009. Sound Synthesis and Sampling. Elsevier Ltd. USA.

Steven Jendri Sokop. Trainer Periferal Antarmuka Berbasis Mikrokontroler Arduino Uno. Jurusan Teknik Elektro-FT. UNSRAT. 